УДК 556: 551.57-58.01/.07

https://doi.org/10.17816/edgcc21184

\title{
ECOSYSTEM PROCESSES IN THE AREA OF THE TOMSK WATER INTAKE
}

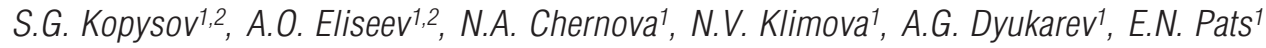 \\ ${ }^{1}$ Institute of Monitoring of Climatic and Ecological Systems SB RAS, Tomsk \\ 2 Tomsk State University, Tomsk
}

Автор для переписки: wosypok@mail.ru

Citation: Kopysov SG, Eliseev A0, Chernova NA, Klimova NV, Dyukarev AG, Pats EN, 2019. Ecosystem processes in the area of the Tomsk water intake. Environmental dynamics and global climate change. 10:91-99. https://doi.org/10.17816/edgcc21184

The influence of the Tomsk water intake on the ecosystems of the Ob-Tom interfluve is studied. It is revealed that the exploitation of the underground water field for almost 50 years has led to the transformation of the natural environment as a result of changes in the hydrological regime in the aeration zone. The most significant changes were observed in hydromorphic ecosystems located in the area of the first well line of the Tomsk water intake, which is associated with both the longest exposure and the feature of the lithological structure. A series of studies has been conducted here since 2000. the estimation of the ecosystems state was done, including the assessment of moisture of ecotopes via phytoindication method. To reconstruct phytocenoses that existed before drying (before 2000), the composition of plant macrofossils of the upper layers of peat was analyzed. There is noted the dependence of changes in the hydrological regime of ecotopes on the dynamics of groundwater levels associated with the operation of the Tomsk water intake against the background of cyclical climate variability. The main changes in the water regime on the territory of the Ob-Tom interfluve occurred at the first stages of the water intake operation in 1970s during the formation of a depression funnel in the area of the first well line (it was before the beginning of our research in 2000). Currently, the transformation processes have slowed down and there is a stable functioning of ecosystems in the new conditions of moisture, established at a more or less constant level, in accordance with the reduced volumes of water intake. Hydroclimatic calculations for the basin of river Poros have shown that the volume of groundwater renewal in the Ob-Tom interfluve exceeds the current volume of water extraction, which excludes or significantly slows down the further transformation of ecosystems.

Key words: water intake influence, Ob-Tom interfluve, drying of mires, method of hydrological and climatic calculations, phytoindication, indicator values of plants.

Исследовано влияние Томского водозабора на экосистемы Обь-Томского междуречья. Выявлено, что эксплуатация в течение почти 50 лет месторождения подземных вод привела к трансформации природной среды в результате изменений гидрологического режима в зоне аэрации. Наиболее значительные изменения отмечены в гидроморфных экосистемах, расположенных в районе действия первой очереди водозабора, что связано как с наиболее продолжительным воздействием, так и особенностью литологического строения. Здесь и проведен очередной цикл исследований, продолжающихся с 2000 года. Дана оценка состояния экосистем, а также увлажнения экотопа фитоиндикационным методом. Для реконструкции фитоценозов, существовавших до обсыхания (до 2000 г.), проведен ботанический анализ верхних слоев торфа. Отмечена зависимость изменения гидрологического режима экотопов с динамикой уровней подземных вод, связанной с работой Томского водозабора на фоне циклической климатической изменчивости. Основные изменения водного режима на территории Обь-Томского междуречья произошли на первых этапах эксплуатации водозабора и формирования в районе первой очереди воронки депрессии, до начала наших исследований в 2000 году. В настоящее время процессы трансформации замедлились и наблюдается устойчивое функционирование экосистем в новых условиях увлажнения, установившегося на более или менее постоянном уровне, в соответствии с пониженными объемами водоотбора. Гидролого-климатические расчеты для бассейна р. Порос показали, что объемы возобновления подземных вод Обь-Томского междуречья превышают текущие объемы водоотбора, что исключает, или существенно замедляет дальнейшую трансформацию экосистем.

Ключевые слова: влияние водозабора, Обь-Томское междуречье, обсыхание болот, метод гидрологоклиматических расчетов, фитоиндикация, экологические шкалы.

\section{BBEQ태ИЕ}

Открытие и введение в эксплуатацию месторождения подземных вод в непосредственной близости от города Томска в палеогеновых горизонтах на территории Обь-Томского междуречья решило важную проблему обеспечения населения чистой питьевой водой. К началу 2000-х гг. объем водоотбора достигал 250 тыс. м $^{3}$ в сутки при утвержденных запасах 260 тыс. м³ . Однако уже в первые годы экс- 
плуатации (с начала 1970-х гг.) в водоносных горизонтах сформировалась обширная воронка депрессии. Глубина сработки водоносных горизонтов по первой очереди скважин водозабора достигала 9-10 м, а по отдельным скважинам - до 15 м [Попов с соавт., 2002]. Сработка уровня подземных вод в эксплуатируемом палеогеновом комплексе усилила переток подземных вод из вышележащих горизонтов, что привело к снижению уровня в четвертичном водоносном комплексе и вызвало активные процессы обсыхания в ландшафтах, примыкающих к линиям водозабора.

На отдельных болотах Обь-Томского междуречья обсыхание проявилось в разной степени - от незначительного по периферии до полного пересыхания торфяной залежи. В напочвенном покрове отмечена смена гидро- и гигрофильных видов растений на менее влаголюбивые гидромезо- и мезофильные [Чернова, 2011]. В почвах выявлено снижение уровня залегания почвенно-грунтовых вод и формирование горизонтов иссушения [Дюкарев и Пологова, 2009, 2011].

Считать ли обсыхание на территориях с широким распространением гидроморфных и полугидроморфных ландшафтов отрицательным или положительным явлением? Во второй половине 20 века на юге таежной зоны Западной Сибири, в том числе и на территории ОбьТомского междуречья были широко развернуты гидролесомелиоративные мероприятия, проводилось осушение болот на больших площадях с целью повышения производительности лесов [Ефремов, 1987; Панченко и Дюкарев, 2015]. Однако осушение не дало ожидаемых результатов и оказалось неэффективным. Производительность лесов выросла мало, но сильно возросла опасность возникновения пожаров и сопутствующих им негативных последствий, в том числе загрязнение атмосферы, снижение ресурсного и экономического потенциала территории, ухудшение рекреационных качеств территории. С учетом негативных последствий, в последнее время не только в России, но и в других странах высказывается мнение о необходимости сократить мелиоративные работы и реанимировать болота, выполняющие важные биосферные функции, в частности сохранения биоразнообразия, баланса круговорота воды, углерода [Williamson et al., 2017; Синюткина с соавт., 2018].

Цель данной работы - оценка современного состояния природной среды Обь-Томского междуречья, выявление негативных последствий, связанных с работой Томского водозабора, и прогноз дальнейшего развития экосистем в зоне его действия.

\section{OБЪEKTЫ И METO@Ы ИCСПEЯOBAHИЙ}

Район исследований - Обь-Томское междуречье - расположен на юге таежной зоны Западной Сибири. Среднегодовая температура $-0.6{ }^{\circ} \mathrm{C}$. Радиационный баланс положительный - 2025 ккал/см². Сумма температур выше 10 градусов составляет $1700-1750{ }^{\circ} \mathrm{C}$ за год. Среднегодовое количество осадков 517 мм. Гидротермический коэффициент 1.1-1.2. Территория относится к зоне умеренного увлажнения, где естественное, климатически обусловленное обсыхание маловероятно [Климат Томска, 1982]. В геологогеоморфологическом отношении Обь-Томское междуречье имеет сложное строение, что связано с историческими факторами его формирования. Здесь древняя равнина, сложенная суглинистыми отложениями, перемыта древними разного возраста ложбинами стока, сложенными отложениями легкого гранулометрического состава от сортированных песков, до слоистых суглинисто-супесчано-песчаных отложений [Дюкарев и Пологова, 2011]. Общая заболоченность территории невысокая - около 20\%. Основные площади болот сосредоточены на террасах и в ложбинах древнего стока. Питание болот повсеместно атмосферное, местами с участием почвенно-грунтовых вод [Платонов, 1963].

Обь-Томском междуречье - экономически активная территория. Здесь развито как лесопользование, так и сельскохозяйственное землепользование, высока рекреационная нагрузка [Панченко и Дюкарев, 2015]. Из хозяйственной деятельности, способствующей гидрологическим трансформациям, следует отметить лесомелиоративные мероприятия и осушение болот в 1960-1970-е гг. Для разработки технологий осушения и оценки результатов лесомелиоративных работ на территории междуречья в это же время был создан «болотный» стационар ИЛ СО РАН. Наиболее значимым и глубоким фактором воздействия на природную среду следует отметить введение в эксплуатацию в 1972 г. «Томского водозабора». Водоотбор ведется с глубин более 80 м. Однако показатели химического состава добываемой питьевой воды свидетельствуют о том, что недостаток воды в эксплуатируемых геологических слоях компенсируется за счет как выше- так и ниже залегающих водоносных горизонтов [Попов с соавт., 2002].

В связи с высокой ландшафтной неоднородностью Обь-Томского междуречья, выявленные здесь гидрологические трансформации по-разному проявились на отдельных участках территории и разных типах ландшафта. Наиболее подвержены гидрологическим трансформациям оказались полугидроморфные и гидро- 


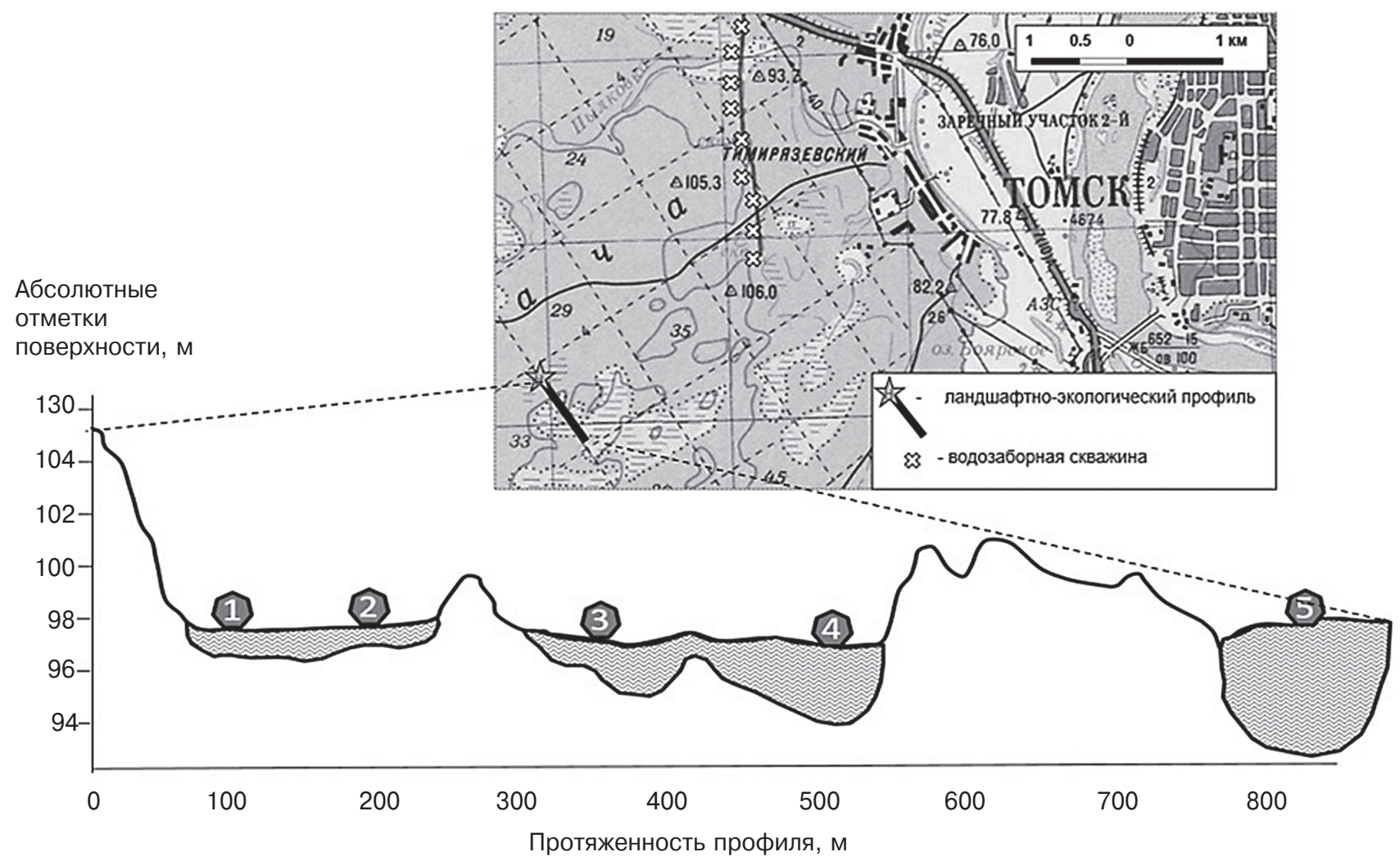

Pnc. 1. Ландшафтно-экологический профиль в зоне действия Томского водозабора. Цифрами 1-5 обозначены места отбора торфяных скважин

Fis. 1. Landscape and ecological transect in the area of operation of the Tomsk water intake. Numbers $1-5$ indicate the points of peat sampling

морфные ландшафты ложбин древнего стока [Дюкарев и Пологова, 2009]. Для исследования процессов, протекающих в ландшафтах, и выявления роли водозабора в их трансформации нами заложена серия ландшафтно-экологических профилей. В настоящей работе приведены результаты исследования на ландшафтно-экологическом профиле, заложенном в зоне максимального обсыхания (2.5-3 км от первой линии скважин водозабора), охватывающем все элементы рельефа ложбины древнего стока: гривы разной высоты и заболоченные межгривные понижения, различающиеся по мощности накопленного торфа (рис. 1). Профиль общей протяженностью 820 м ориентирован на юго-восток и проложен по просеке между 33 и 34 кварталами Тимирязевского лесхоза. Географические координаты начала профиля 56²6'43" с.ш. 8449'36" в.Д. Важно отметить, что при рекогносцировочных исследованиях [Дюкарев и Пологова, 2009] вблизи места заложения профиля не было выявлено осушительной системы гидромелиорации. Ближайшее осушенное болото - Чагинское - расположено в 3,5 км на северо-восток и не сообщается с исследованными нами болотами.
На ландшафтно-экологическом профиле в 2000, 2007, 2018 гг. проведены геоботанические описания всех растительных сообществ по элементам рельефа. В данной работе основное внимание уделено анализу гидроморфных и полугидроморфных экосистем, наиболее подверженных гидрологическим трансформациям. Для реконструкции фитоценозов болот, существовавших до введения месторождения в эксплуатацию и начала обсыхания, проведен ботанический анализ верхних слоев торфа из скважин, отобранных в центральных частях болот (см. рис. 1, точки 1-5). Оценка экологической структуры растительных сообществ проведена с использованием экологических групп видов, предложенных для болот юго-востока Западной Сибири Е.Д. Лапшиной [2003]. Также рассчитаны условия увлажнения местообитаний методом фитоиндикации с помощью экологических шкал Л.Г. Раменского [Раменский с соавт., 1956], что позволило проследить ход динамики увлажнения как до, так и после начала обсыхания. При расчетах учтено обилие видов и их индикаторная значимость в соответствии с рекомендациями [Зверев и Бабешина, 2009]. 
Моделирование условий увлажнения производилось по методу гидролого-климатических расчетов [Карнацевич с соавт., 2011] на основе данных о суточных осадках и температурах воздуха за период с 1936 по 2017 гг. для ближайшей метеостанции - Томск - из базы данных ВНИГМИ-МЦЦ [Булыгина с соавт., 2019].

\section{PEЗУПЬTATbI И ОБСУЖดEHИE}

\section{Динамика растительных сообществ, связанная с изменением гидрологического режима территории}

Анализ динамики фитоценозов показал, что выявленное на Обь-Томском междуречье изменение гидроморфных ландшафтов происходило неравномерно как в пространстве, так и во времени. Так, в точках 1-3, где мощность торфяной залежи до обсыхания не превышала 2 м произошли наиболее значимые изменения. В точке 1 исходная мощность торфяной залежи (реконструированная по плотности сложения) была около 180 см. Однако уже к 2000 году, в результате обсыхания, уплотнения и частично минерализации торфа мощность торфяной залежи уменьшилась до 1 м. К настоящему времени (2019 год) мощность торфяной залежи уменьшилась еще на 35 см. В точке 2 также продолжается уменьшение мощности торфяной залежи с 0,9 м в 2000 году, до 0,5 м в 2019 г. С поверхности торф стал рыхлый, приобрел «Пылеватое» сложение, потерял способность впитывать и удерживать влагу. Уровень болотно-грунтовых вод обнаруживается только ранней весной и то за пределами торфяной толщи. Судя по ботаническому составу торфа (табл.), ранее здесь были травяные и травяно-сфагновые болота-топи с преобладанием аэрогидрои субгидрофитов - растений, предпочитающих более или менее обводненные местообитания (Carex limosa, Menyanthes trifoliata, Sphagnum subsecundum). Но еще до начала мониторинговых исследований (до 2000 г.) увлажнение почв сильно уменьшилось (на 13-18 ступеней экологической шкалы Л.Г. Раменского) (рис. 2),

Таблица 2 / Table 2

Трансформация сообществ болот на Обь-Томском межАуречье

Transformation of hydromorphic ecosystems in the Ob-Tom interfluve

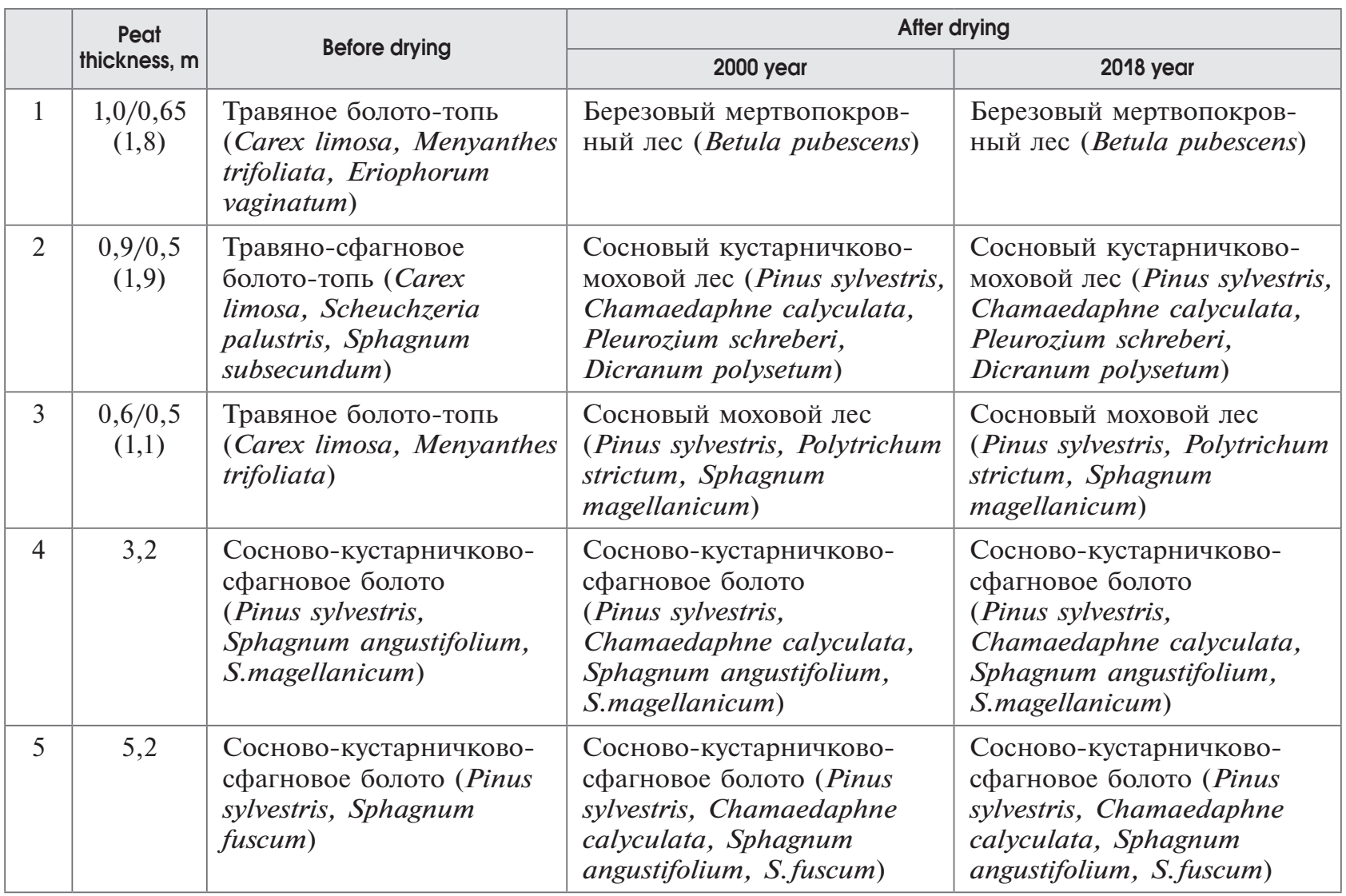

Примечание. Мощность торфа (м) в числителе - 2000 год, в знаменателе - 2019 год (в скобках приведена исходная мощность торфяной залежи, рассчитанная по изменению плотности сложения).

Note. Peat thickness (m) in the numerator - 2000, in the denominator - 2019 (in brackets, the initial thickness of the peat deposit, calculated from the change in the peat density). 


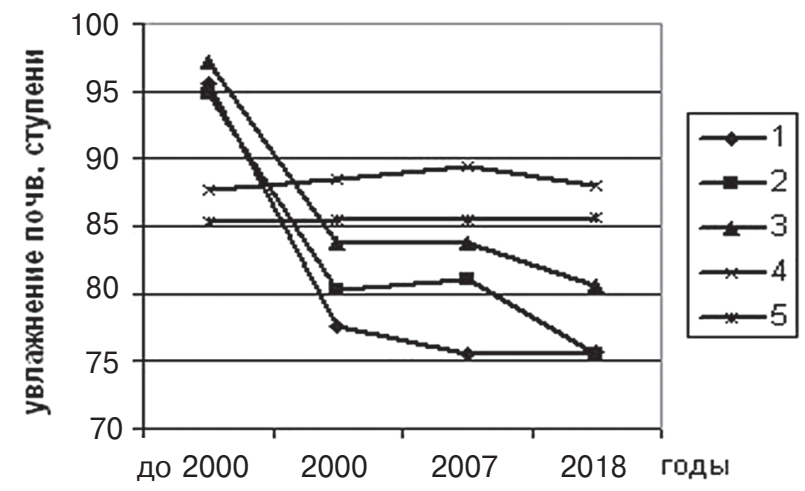

Pnc. 2. Динамика увлажнения почв в фитоценозах межгривных западин на Обь-Томском междуречье. Номера точек такие же, как на рис. 1 и в таблице

Fí. 2. Dynamics of soil moisture in the phytocenoses of inter-ridge depressions in the Ob-Tom interfluve. The point numbers are the same as in Fig. 1 and in the table

торфяная залежь пересохла и уплотнилась, на месте болот сформировались разреженные леса из сосны и березы, мертвопокровные, реже моховые. В дальнейшем не наблюдалось значительных изменений увлажнения почв ни в большую, ни в меньшую сторону - колебания этого параметра составляли от 0-1 до 3(5) ступеней (рис. 2). Соответственно на месте топяных фитоценозов уже в течение почти 20 лет устойчиво сохраняются лесные сообщества с преобладанием растений, предпочитающих средние условия увлажнения - мезофитов и гидромезофитов (Betula pubescens, Pinus sylvestris, Pleurozium schreberi, Polytrichum strictum, Sphagnum angustifolium), и меньшим участием субгидрофитов.

В целом, описанные изменения фитоценозов сходны с теми, что наблюдаются после гидромелиорации болот и детально описаны С.П. Ефремовым [1987] на Обь-Томском междуречье. Однако следует отметить, что если современный древостой, сформировавшийся в начальные фазы изменения гидрологического режима, выглядит почти нормальным, то современное возобновление кедра и сосны угнетенным, что связано с недостатком влаги. При достаточной для лесовозобновления численности (12-20.5 тыс. шт./га) его средняя высота 42 см, а средний возраст 15-16 лет, в то время как у такого же подроста из естественных местообитаний [Николаева и Панов, 2012] - приросты в 2-3 раза выше. Кроме того, процессы формирования напочвенного покрова в исследованных нами лесах протекают очень медленно. Вероятно, это связано с недостаточным увлажнением местообитаний, сложившимся после обсыхания. Так, Т.Т. Еф- ремова с соавт. [2011] отмечали снижение продуктивности древостоев на обсохших торфяных почвах уже при снижении уровня почвенногрунтовых вод до глубины 50 см. А в нашем случае он снизился на глубину более 2,5 м [Дюкарев и Пологова, 2009].

Болота с более мощной (более 3 м) залежью (точки 4 и 5) обсохли в меньшей степени. В центральной их части (в месте отбора торфа) существенных изменений условий местообитаний, в частности увлажнения почв, не происходило (рис. 2). Как ботанический состав верхних слоев торфа, так и современные наблюдения указывают, что здесь ранее, как и в настоящее время, существовали болотные сосновые кустарничково-сфагновые сообщества с преобладанием гидромезофитов и субгидрофитов (Pinus sylvestris (болотная форма), Chamaedaphne calyculata, Sphagnum angustifolium, S. magellanicum, S. fuscum) (табл.). Признаки обсыхания обнаружены только по периферии этих болотных массивов. В точке 4 они выражаются в формировании по краю болота узкой полосы мертвопокровного сосново-березового леса, приуроченного к участкам пересохшей торфяной залежи. В точке 5 изменения более слабые - по периферии торф не пересох, но в напочвенном покрове преобладают не гидромезофитные мхи (Sphagnum angustifolium, S. fuscum), а мезофитные (Pleurozium schreberi). Все перечисленные признаки обсыхания были выявлены уже в самом начале исследований (в 2000 г.), и дальнейшего изменения в растительном покрове не наблюдалось. Однако отмечено усиление просадки в краевой части болота (на границе болота и минеральной гривы), которое продолжается и в настоящее время.

Таким образом, динамика фитоценозов в межгривных западинах происходила следующим образом. Максимальное обсыхание произошло еще до 2000 г., а с 2000 г. и до настоящего времени существенных изменений ни в условиях местообитаний (в частности, увлажнении почв), ни в структуре фитоценозов (видовой, экологической) не отмечено. Несколько усилились только просадочные явления на границе болота и минеральной гривы.

\section{Динамика гидроклиматических условий}

На основе данных гидрометеостанции Томск [Булыгина с соавт., 2019] мы провели анализ динамики гидротермического режима за период с 1936 по 2017 гг. (рис. 3). Кроме динамики годовой увлажненности (рис. 3 , а) отдельно анализировалась увлажненность за май-август (рис. 3, б), так как, согласно [Коломыц, 2018], 


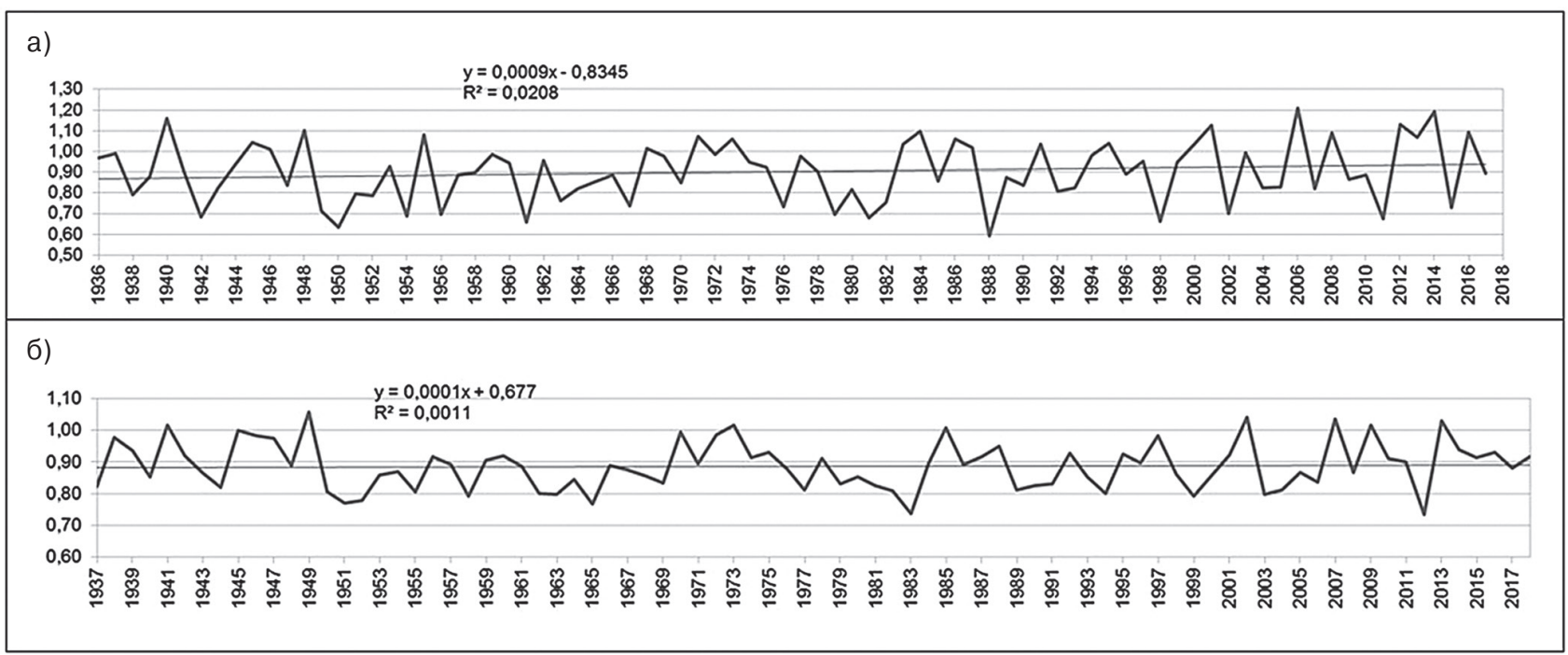

Pис. 3. Динамика коэффициента увлажнения (осадки/испаряемость) (а) и относительной влажности деятельного слоя за май-август (б)

Fiङ. 3. Dynamics of moisture coefficient (precipitation/evaporation) (a) and relative moisture of the active layer for May-August (b)

именно летнее влагосодержание почвы служит основным звеном передачи гидротермических сигналов с глобального уровня на региональный и локальный. Выявлен незначительный тренд (рис. 3, а) с 0.88 до 0.92, обусловленный увеличением осадков относительно теплоэнергетических ресурсов испарения (испаряемости). Однако увеличение осадков больше характерно для зимнего периода и в первую очередь способствует росту половодья, поэтому влажность деятельного слоя за вегетационный период май-август (рис. 3, б) не отражает этот тренд, что указывает на стабильность климатических условий для вегетации растительности в многолетнем режиме. К подобным выводам пришли и О.В. Мезенцева с соавторами [2010], исследовавшие пространственно-временную динамику характеристик естественной тепловлагообеспеченности Западной Сибири. Они показали отсутствие достоверного климатического тренда коэффициента увлажнения, а также получили разнонаправленные линейные тренды характеристик естественного увлажнения и теплообеспеченности, которые дают право сомневаться в однонаправленности климатического процесса в последние десятилетия. Отсутствие длительного (многолетнего) однонаправленного изменения коэффициента увлажнения свидетельствует о том, что причиной смены растительных сообществ, наблюдаемой на ОбьТомском междуречье, была не динамика гидротермического режима.

Отметим также, что при обсыхании болот в межгривных понижениях глубина залегания почвенно-грунтовых вод увеличилась более чем на 2 м (с глубины 0,1-0,2 м, свойственной для мезотрофных топей согласно [Лапшина, 2010], до 2,5-3,0 м по наблюдениям А.Г. Дюкарева и Н.Н. Пологовой [2009]). Такое изменение значительно больше, чем выявленная при мониторинге амплитуда естественных колебаний уровня болотных вод в годы с разными погодными условиями, которая не превышала 15-20 см [Дюкарев и Пологова, 2009].

Поэтому, можно утверждать, что выявленная на Обь-Томском междуречье динамика условий увлажнения и растительности обусловлена не климатическими процессами, а антропогенным нарушением гидрологического режима в результате многолетней деятельности водозабора и соответствующими изменениями условий произрастания растений. В пользу этого заключения свидетельствует и пространственная неравномерность обсыхания экосистем. В то время как увлажнение местообитаний межгривных понижений существенно уменьшилось, на гривах таких изменений отмечено не было. Это указывает на связь выявленных процессов обсыхания с динамикой уровней подземных вод. Не отмечено существенных изменений и в экосистемах, формирующихся на древних равнинах, сложенных суглинистыми отложениями. Другими исследователями также отмечены негативные процессы, связанные с деятельностью водозабора [Попов с соавт., 2002]. При вводе его в эксплуатацию это влияние в значительной мере перекрывало ход естественной динамики подземных вод. Так, в исследованиях О.Г. Савичева и Ю.В. Макушина [2004] в разных сква- 
жинах на территории Томской области, не подверженных антропогенному влиянию, отмечен постепенный подъем уровней подземных вод с 60-70-х гг. 20 века. В то же время на Обь-Томском междуречье с момента начала работы Томского водозабора (1972 г.) наблюдалось закономерное снижение уровней воды в скважинах и формирование обширной воронки депрессии [Попов с соавт., 2002]. Важно отметить, что изменение уровней подземных вод происходило не постепенно, а скачком. Основная их сработка отмечена в 70-80-е гг. - от 7-9 м до 12-16 м по первой наиболее эксплуатируемой очереди скважин [Попов с соавт., 2002; Состояние ..., 2017, с. 97]. Затем, после установления определенного более или менее постоянного объема воды, изымаемой Томским водозабором, наблюдались незначительные колебания уровней - в пределах 1-2 м, связанные с режимом эксплуатации водозаборных скважин и климатическими факторами [Савичев и Шмаков, 2012; Состояние ..., 2017]. Таким образом, динамика уровней подземных вод на Обь-Томском междуречье, обусловленная работой Томского водозабора, имеет тот же характер, что и динамика изменений увлажнения местообитаний, выявленная фитоиндикационным методом. Тесная связь обсыхания болот на междуречье с работой Томского водозабора подтверждается и территориальной приуроченностью зоны максимального обсыхания к центру воронки депрессии подземных вод [Дюкарев и Пологова, 2011].

Месторождение подземных вод Обь-Томского междуречья относится к возобновляемым природным ресурсам, поскольку питание палогенового комплекса, эксплуатируемого Томским водозабором, - инфильтрационное [Попов с соавт., 2002]. Расчеты распределения климатического стока на междуречье позволили нам оценить ежегодные объемы возобновления подземных вод. В качестве модели для расчетов мы использовали р. Порос - левый приток р. Томь. В работе Л.И. Дубровской и H.А. Ермашовой [2001], по данным 19731998 гг., отмечается тенденция снижения стока p. Порос, возможно, связанная с увеличением расходования верховодки на питание водоносного горизонта кочковской свиты, уровень которого вблизи долины р. Томь существенно снизился за счет работы Томского водозабора. Но уже по данным до 2001 года [Савичев с соавт., 2003] сделан вывод о том, что изменения водного режима р. Порос связаны не только с антропогенными факторами. Если рассматривать период наблюдений с 1974 по 2015 гг., то средний расход воды в р. Порос увеличился на 8\%, по сравнению с 1974-2001 гг., и составляет
0.49 м/с. Это увеличение на $3 \%$ превышает точность гидрометрического учёта стока. Таким образом, сток воды в р. Порос слабо зависит от количества забора подземных вод, что указывает на его слабую гидрологическую связь с горизонтом подземных вод, так как формируется на территории древней равнины, сложенной суглинистыми и глинистыми отложениями. Об этом же говорит и то, что, начиная с 1997 года, согласно [Савичев и Шмаков, 2012], на исследуемой территории отмечается рост уровня подземных вод.

Смоделированный по методу гидрологоклиматических расчётов среднемноголетний климатический сток на водосборе р. Порос у с. Зоркальцево составляет 158 мм, а измеренный гидрометрический слой стока только 49 мм. Следовательно, среднемноголетнее инфильтрационное питание подземных вод составляет 109 мм в год. Столь значительное питание объясняется обилием западин, в основном воронкообразных, являющихся зонами активного пополнения запасов подземных вод по макропорам [Копысов, 2015]. Среднемноголетний возобновляемый подземный сток Обь-Томского междуречья, учитывая дренируемую Томским подземным водозабором площадь (1500 км²), можно оценить в 650 тыс. м $^{3}$ в сутки. Из них допустимо отбирать только третью часть, т. е. 215 тыс. м $^{3}$ в сутки, что на $20 \%$ меньше утвержденных запасов. Если в начале 2000-х гг. объем водоотбора достигал 250 тыс. м ${ }^{3}$ в сутки, то в 2018 году Томским водозабором в среднем ежесуточно выкачивалось только 119 тыс. м ${ }^{3}$ [Состояние ..., 2019, с. 103]. Сейчас объем водоотбора гораздо меньше расчетных объемов возобновления подземных вод и в последнее время поддерживается на стабильном уровне. Это свидетельствует и о стабилизации экологических условий произрастания растений на территории Обь-Томского междуречья, а значит дальнейшего катастрофического разрастания очагов гидротрансформаций, как это предполагалось ранее [Дюкарев и Пологова, 2011], не предвидится.

\section{AKחIOUEHHE}

Исследование лесных и болотных экосистем на Обь-Томском междуречье показало, что значительное изменение условий местообитаний, вызвавшее обсыхание территории, произошло еще до 2000 г. и сказалось главным образом на болотах. Затем, в ходе длительного мониторинга обсохших лесоболотных комплексов, начатого в 2000 г., дальнейших существенных изменений условий местообитаний и соответственно экосистем не выявлено. Подобная 
динамика обсыхания, на фоне относительного постоянства климатических условий (гидротермического режима) в многолетнем разрезе, объясняется изменением уровней подземных вод на междуречье, обусловленным в значительной мере вводом в эксплуатацию Томского водозабора - рост объемов отбора воды и соответствующая сработка водоносных горизонтов в 1970-1980-е гг., а затем выход на определенный более или менее постоянный уровень к 2000-м гг. и даже снижение водоотбора в последние годы.

Установившиеся в настоящее время объемы водоотбора на междуречье значительно меньше объемов ежегодного возобновления подземных вод. Поэтому дальнейшего усиления обсыхания территории не ожидается. Подвергшиеся ранее обсыханию болотные экосистемы Обь-Томского междуречья теперь устойчиво функционируют в условиях вновь сложившегося уровня грунтовых, почвенно-грунтовых и болотных вод.

\section{ПИTEPATYPA}

1. Булыгина ОН, Разуваев ВН, Александрова ТМ, 2014. Описание массива данных суточной температуры воздуха и количества осадков на метеорологических станциях России и бывшего СССР (TTTR). Свидетельство о государственной регистрации базы данных № 2014620942. http://meteo.ru/data/162-temperatureprecipitation\#описание-массива-данных.

2. Дубровская ЛИ, Ермашова НА, 2001. Особенности гидрологического режима малых рек Обь-Томского междуречья. Вестник Томского государственного университета. 274:101-103.

3. Дюкарев АГ, Пологова НН, 2009. Водный режим почв в зоне влияния Томского водозабора. Вестник Томского государственного университета. 324:363-371.

4. Дюкарев АГ, Пологова НН, 2011. Состояние природной среды в зоне действия Томского водозабора. Сибирский экологический журнал. 1:123-134.

5. Ефремов СП, 1987. Пионерные древостои осушенных болот. Наука. Новосибирск: 249 с

6. Ефремова ТТ, Ефремов СП, Аврова АФ, Мелентьева НВ, 2011. Лесоэкологическая оценка гидротермических условий осушенных болот Западной Сибири. Сибирский вестник сельскохозяйственной науки. 217:58-65.

7. Зверев АА, Бабешина ЛГ, 2009 Оценка условий местообитаний сфагновых мхов Западно-Сибирской равнины по ведущим экологическим факторам: Объекты, материалы и методические основы. Вестник Томского государственного университета. 325:167-173.]

8. Карнацевич ИВ, Бикбулатова ГГ, Ряполов КВ, 2011. Перспективы генетического метода расчета элементарного стока по суточным интервалам. Омский научный вестник. 104:224-231.

9. Коломыц ЭГ, 2018. Избранные очерки географической экологии: Ч.І. Базовый ландшафтно-экологический ана- лиз. Самарская Лука: Проблемы региональной и глобальной экологии. 27:15-129. doi: 10.24411/2073-10352018-10002

10. Копысов СГ, 2015. Многолетний гидрологический режим западин юга таежной зоны Западной Сибири. Известия РАН. Серия географическая. 5:130-134.

11. Кошинский СД, ред, 1982. Климат Томска. Гидрометеоиздат, Ленинград: 176 с.

12. Лапшина ЕД, 2003. Флора болот юго-востока Западной Сибири. Изд-во Том. ун-та, Томск: 296 с.

13. Лапшина ЕД, 2010. Растительность болот юго-востока Западной Сибири. Изд-во НГУ, Новосибирск: 186 с.

14. Льготин ВА, ред, 2017. Состояние геологической среды (недр) территории Сибирского федерального округа в 2016 г.: Информационный бюллетень. 174 с.

15. Льготин ВА, ред, 2019. Состояние геологической среды (недр) территории Сибирского фредерального округа в 2018 г.: Информационный бюллетень. 218 с.

16. Мезенцева ОВ, Карнацевич ИВ, Березин ЛВ, 2010. Исследования пространственно-временной динамики характеристик естественной тепловлагообеспеченности Западной Сибири и вопросы устойчивости развития сельского хозяйства. Вестник Томского государственного университета. 331:210-212.

17. Николаева СА, Панов АН, 2012. Сезонный рост и развитие побегов кедра сибирского под пологом сосновых и березовых насаждений. Лесоведение. 3:59-68.

18. Панченко ЕМ, Дюкарев АГ, 2015. Зонирование территории Обь-Томского междуречья по эколого-функциональному принципу. Вестник Томского государственного университета. 394:250-260. doi: 10.17223/15617793/394/39

19. Платонов ГМ, 1963. Болота северной части междуречья Оби и Томи. Заболоченные леса и болота Сибири, с. 6595. Москва, Изд-во АН СССР. С. 65-95.

20. Попов ВК, Коробкин ВА, Лукашевич ОД, Золотарёва ВВ, Галямов ЮЮ, 2002. Формирование и эксплуатация подземных вод Обь-Томского междуречья. Изд-во Томского архитектурно-строительного университета. Томск: $138 \mathrm{c}$.

21. Раменский ЛГ, Цаценкин ИА, Чижиков ОН, Антипин НА, 1956. Экологическая оценка кормовых угодий по растительному покрову. Сельхозгиз, Москва: 472 с.

22. Савичев ОГ, Колоколова ОВ, Краснощеков СЮ, Шварцева ОС, 2003. Водный режим реки Порос как индикатор природно-антропогенных процессов в Обь-Томском междуречье. Вестник Томского государственного университета. Приложение 3 (IV):151-152.

23. Савичев ОГ, Макушин ЮВ, 2004. Многолетние изменения уровней подземных вод верхней гидродинамической зоны на территории Томской области. Известия Томского политехнического университета 307:60-63.

24. Савичев ОГ, Шмаков АВ, 2012. Вертикальная зональность и внутригодовые изменения химического состава вод Тимирязевского болота (Томск, Западная Сибирь). Известия Томского политехнического университета. 320:156-161.

25. Синюткина АА, Гашкова ЛП, Малолетко АА, Магур МГ, Харанжевская ЮА, 2018. Трансформация поверхности 
и растительного покрова осушенных верховых болот юго-востока Западной Сибири. Вестник Томского государственного университета. Биология. 43:196-223. doi: 10.17223/19988591/43/10

26. Чернова НА, 2011. Трансформация растительного покрова топяных местообитаний болот при обсыхании территории Обь-Томского междуречья. Вестник Том. гос. ун-та. Серия биология. 1:61-74.
27. Williamson J, Rowe E, Reed D, Ruffino L, Jones P, Dolan R, Buckingham H, Norris D, Astbury S, Evans CD, 2017. Historical peat loss explains limited short-term response of drained blanket bogs to rewetting. Journal of Environmental Management. 188:278-286. doi: 10.1016/j.jenvman.2016.12.018 